CORRECTION

https://doi.org/10.1038/s41586-018-0505-4

\title{
Author Correction: Inositol phosphates are assembly co-factors for $\mathrm{HIV}-1$
}

Robert A. Dick, Kaneil K. Zadrozny, Chaoyi Xu,

Florian K. M. Schur, Terri D. Lyddon, Clifton L. Ricana,

Jonathan M. Wagner, Juan R. Perilla, Barbie K. Ganser-Pornillos,

Marc C. Johnson, Owen Pornillos \& Volker M. Vogt

Correction to: Nature https://doi.org/10.1038/s41586-018-0396-4, published online 01 August 2018.

In the 'Data availability' section of this Letter, the Protein Data Bank (PDB) accessions were incorrectly listed as ' $6 \mathrm{BH} 5,6 \mathrm{BHT}$ and $6 \mathrm{BHS}$ ' instead of '6BHR, 6BHT and 6BHS'; this has been corrected online. 